\title{
Plasma Lactate as a Prognostic Biomarker in Acute Carbon Monoxide Toxicity
}

\author{
Hany M. Abd El Razik and Mahmoud B. Abd El Wahab²
}

\author{
${ }^{1}$ Fellow of Clinical Toxicology \\ ${ }^{2}$ Fellow of Biochemistry \\ Poison Control Center of Ain Shams University Hospitals, Cairo, Egypt.
}

All rights reserved.

\begin{abstract}
Patients with acute carbon monoxide (CO) poisoning have been found to have a correlation between initial clinical severity on admission and blood lactate levels. Recently, it is suggested that the lactate level may be a useful prognostic factor in cases study. The purpose of this study was to assess whether plasma lactate levels can be used as a biomarker for the assessment of severity and outcome of acute carbon monoxide poisoning. Selected Forty patients whom presented to the Poison Control Centre (PCCA) of Ain Shams University Hospitals after acute CO poisoning, over 1 year, were included in this study. Based on clinical criteria, patients were classified into 3 groups (mild, moderate and severe). Blood $\mathrm{pH}$, Carboxyhemoglobin (COHb), blood sugar (B.S), and lactate level were estimated in the blood of all patients. Our results revealed that the blood lactate level was significantly increased in all poisoned patients and the dead patients showed significant increase of blood lactate at time of admission when compared with the survived patients. The correlation study revealed positive correlation between plasma lactate level with B.S levels, $\mathrm{COHb}$ levels and the delay time and negative correlation with blood $\mathrm{pH}$. It is concluded that the initial blood lactate may correlate with the patient outcomes and prove to be a useful prognostic factor in acute $\mathrm{CO}$ poisoning. Thus lactate level is recommended to be considered in cases of acute $\mathrm{CO}$ poisoning.
\end{abstract}

\section{Introduction}

$\mathrm{C}$ arbon monoxide (CO) is a colourless, odourless gas produced by incomplete combustion of carbonaceous material. It is formed as a byproduct of burning organic compounds (Prockop and Chichkova, 2007).

$\mathrm{CO}$ poisoning is associated with tissue hypoxia due to the reduction of the oxygen-carrying capacity of the blood and the concomitant shift of the oxyhemoglobin dissociation curve to the left. This tissue hypoxia leads to systemic acidosis due to the accumulation of lactic acid (Bateman, 2003).

$\mathrm{CO}$ toxicity leads to impaired oxygen delivery and utilization at the cellular level. It affects different sites within the body and has its most profound impact on the organs with the highest oxygen requirement (e.g., brain, heart). Following severe intoxication, patients display central nervous system (CNS) pathology, including white matter demyelination and focal areas of necrosis especially in tissues with low oxygen demand (watershed area), suggesting elements of hypoperfusion and hypoxia (Weaver, 2009). Carbon monoxide (CO) poisoning results in various neuropsychological impairments and delayed encephalopathy. However, factors related to these outcomes are unknown (Pepe et al., 2011).

\section{Objective}

The aim of this study is to assess if plasma lactate level could be used as a biomarker for assessment of severity and outcome of acute carbon monoxide poisoning.

\section{Methodology}

This study was conducted in Poison Control Centre (PCCA) of Ain Shams University Hospitals from November 2010 to November 2011 and it included selected 40 patients with acute carbon monoxide poisoning of both sexes with different ages (The patients ages ranged from 13 to 60 years), they were 29 men and 11 women and the duration of exposure to $\mathrm{CO}$ varied between 1 and $14 \mathrm{~h}$. In addition fifteen healthy non-smoker volunteers (matched age and sex) served as control. Patients with history of head trauma or evidence of cardiac toxicity and patients who were resuscitated were excluded from the study. 
The patients were divided into the following 3 groups according to the clinical grading of carbon monoxide poisoning (table 1) (Tomaszewski, 2006):

- Group I: (mild group) Included 10 patients with mild symptoms and signs

- Group II: (moderate group) Included 15 patients with moderate symptoms and signs

- Group III: (severe group) Included 15 patients with severe symptoms and signs

- Group IV: (control group) Included 15 healthy non-smoker volunteers.

Table (1): Clinical signs and symptoms in different grades of carbon monoxide poisoning (Tomaszewski, 2006).

\begin{tabular}{|l|l|}
\hline \multicolumn{1}{|c|}{ Grade } & \multicolumn{1}{|c|}{ Signs and symptoms } \\
\hline Mild & $\begin{array}{l}\text { Headache, Nausea, Vomiting, Dizziness, } \\
\text { Blurred vision }\end{array}$ \\
\hline Moderate & $\begin{array}{l}\text { Confusion, Syncope, Weakness, Chest pain, } \\
\text { Dyspnea, Tachycardia, Tachypnea, } \\
\text { Rhabdomyolysis }\end{array}$ \\
\hline Severe & $\begin{array}{l}\text { Palpitations, Dysrhythmias, Hypotension, } \\
\text { Myocardial ischemia, Cardiac arrest, } \\
\text { Respiratory arrest, Pulmonary edema, } \\
\text { Seizures, Coma }\end{array}$ \\
\hline
\end{tabular}

Written informed consent was obtained from all patients and control group or from their legal next kin. All groups were subjected to full medical history, general, and neurological examination. Blood sample were taken from all patients and the control group on admission for measuring carboxyhemoglobin, blood $\mathrm{pH}$, blood lactate and plasma glucose level.

\section{Sampling}

- One cubic centimetre of arterial blood was collected on heparinaized syringe under aseptic precaution for measuring blood $\mathrm{pH}$ and carbon monoxide levels by ABL 855 blood analyzer semen's diagnostic.

- Four cubic centimetres of venous blood were collected and centrifuged for 4 minutes at $3000 \mathrm{rpm}$ at ambient temperature, and then plasma glucose and plasma lactate levels were measured immediately. Plasma glucose levels were measured by spectrophotometry method (Trinder, 1969) and plasma lactate concentrations were determined by an enzymatic method (Marbach and Weil, 1967).

The obtained results were statistical analysed by using SPSS windows-version 8 . The mean and standard deviation were calculated and used for description of quantitative variables. Student t-test was used for comparison between two groups; correlation coefficient was done to test the relation between each two variables.

In all tests the probability $(\mathrm{P})$ was used; if $\mathrm{P}>0.05$ the relation is non-significant, while if $\mathrm{P} \leq 0.05$ the relation is significant.

\section{Results}

Table (2) shows that half of patients (20 patients, 50\%) were found in age group of (21-40) years. Patients under the age of twenty years represented 12 patients (30\%), followed by patients in the age group of 41-60 years represented 8 patients (20\%). 29 patients ( $72.5 \%$ ) were males and 11 patients ( $27.5 \%$ ) were females. the majority of patients 30 patients ( $75 \%$ ) were from rural areas and 10 patients ( $25 \%$ ) were from urban areas.

Table (3) shows that the commonest clinical manifestation was nausea and vomiting which was noticed in all patients (100\%) and this was followed by headache in 30 patients $(75 \%)$. Blurring of vision, history of syncope and confusion were also observed but less frequently in 25 patients $(62.5 \%), 25$ patients $(62.5 \%)$ and 15 patients $(37.5 \%)$ respectively. Fifteen patients $(37.5 \%)$ were found comatose, and 4 patients $(10 \%)$ presented with convulsion.

Table (4) shows that there was highly significant decrease in blood $\mathrm{pH}$ in group II \& III in comparison to control group IV, while no significant difference in group I when compared with control group IV.

Table (5) shows that there was no significant difference in the blood $\mathrm{pH}$ in dead patients in comparison with survived patients among group III.

Table (6) shows that there was very highly significant increase in plasma concentration of $\mathrm{COHb}$ in all groups of patients in comparison to control group.

Table (7) shows that there was no significant difference in $\mathrm{COHb}$ level in dead patients in comparison with survived patients among group III.

Table (8) shows that there was highly significant increase in blood sugar level in group III \& group II in comparison to control group IV, while there was no significant difference between group I and control group IV.

Table (9) shows that there was significant increase in blood sugar in dead patients in comparison with survived patients in group III.

Table (10) shows that there this very highly significant increase in the plasma lactate level in all groups of patients in comparison to control group.

Table (11) shows that there was highly significant increase in the plasma lactate level in dead patients in comparison with survived patients among group III.

Table (12) shows that there was strong positive correlation between BS levels and plasma lactate levels, and weak positive correlation between $\mathrm{COHb}$ levels and plasma lactate levels, while there is strong negative correlation between $\mathrm{PH}$ and plasma lactate levels.

Table (13) shows that there was strong positive correlation between delay time and plasma lactate level

Table (14) shows that the period of stay in mild cases is $<1$ day, while in moderate cases is from 1-2 day and in severe cases is more than 2 day. 
Table (15) shows that Mortality was four patients out of 40 patients poisoned with acute carbon monoxide poisoning $=10 \%$ and all were from group III.

Table (2): Distribution of sociodemographic criteria (age, sex, and residence) among the selected 40 patients with acute carbon monoxide poisoning.

\begin{tabular}{|c|c|c|}
\hline Parameter & Number & Percent (\%) \\
\hline \multicolumn{3}{|c|}{ (1) Age categories } \\
\hline$\leq 20$ years & 12 & $30 \%$ \\
\hline$>20-40$ years & 20 & $50 \%$ \\
\hline$>40-60$ years & 8 & $20 \%$ \\
\hline \multicolumn{3}{|l|}{ (2) Sex } \\
\hline Male & 29 & $72.5 \%$ \\
\hline Female & 11 & $27.5 \%$ \\
\hline \multicolumn{3}{|l|}{ (3) Residence } \\
\hline Rural & 30 & $75 \%$ \\
\hline Urban & 10 & $25 \%$ \\
\hline
\end{tabular}

Table (3): Incidence of clinical manifestations in the selected 40 patients with acute carbon monoxide poisoning.

\begin{tabular}{|l|c|c}
\hline Clinical manifestations & Number & Percent (\%) \\
\hline Nausea \&vomiting & 40 & $100 \%$ \\
\hline Headache & 30 & $75 \%$ \\
\hline Blurring of vision & 25 & $62.5 \%$ \\
\hline history of syncope & 25 & $62.5 \%$ \\
\hline Confusion & 15 & $37.5 \%$ \\
\hline Coma & 15 & $37.5 \%$ \\
\hline Convulsion & 4 & $10 \%$ \\
\hline
\end{tabular}

Table (4): Student (t) test of blood pH in group I, II and III compared to control group IV.

\begin{tabular}{|l|c|c|c|c|}
\hline \multicolumn{1}{|c|}{$\mathbf{p H}$} & $\begin{array}{c}\text { Group I (mild) } \\
\mathbf{N o}=\mathbf{1 0}\end{array}$ & $\begin{array}{c}\text { Group II (moderate) } \\
\mathbf{N o}=\mathbf{1 5}\end{array}$ & $\begin{array}{c}\text { Group III (severe) } \\
\mathbf{N o}=\mathbf{1 5}\end{array}$ & $\begin{array}{c}\text { Group IV(control) } \\
\text { No= 15 }\end{array}$ \\
\hline Mean $\pm \mathrm{SD}$ & $7.37 \pm 0.038$ & $7.32 \pm 0.05$ & $7.28 \pm 0.042$ & $7.393 \pm 0.031$ \\
\hline $\mathrm{t}$ & 1.6613 & 4.8058 & 8.3838 & \\
\hline $\mathrm{P} *$ & 0.1102 & $0.0001 *$ & $0.0001 *$ & \\
\hline \multicolumn{5}{|r}{$\mathrm{P}<0.05=$ significant }
\end{tabular}

Table (5): Student (t) test of blood pH in survived and dead patients of group III.

\begin{tabular}{|l|c|}
\hline \multicolumn{1}{|c|}{$\begin{array}{c}\text { Group III (severe) } \\
\text { No }=\mathbf{1 5}\end{array}$} & pH \\
\hline Survive patients $(\mathrm{No}=11)$ & $7.3 \pm 0.02$ \\
\hline Died patients $(\mathrm{No}=40$ & $7.27 \pm 0.04$ \\
\hline $\mathrm{t}$ & 1.9748 \\
\hline $\mathrm{P} *$ & 0.0699 \\
\hline \multicolumn{2}{|c|}{$* \mathrm{P} \leq 0.05=$ significant. }
\end{tabular}

Table (6): Student (t) test of carboxyhemoglobin (COHb) level in group I, II and III compared to control group IV.

\begin{tabular}{|l|c|c|c|c|}
\hline COHb (\%) & $\begin{array}{c}\text { Group I (mild) } \\
\text { No= 10 }\end{array}$ & $\begin{array}{c}\text { Group II (moderate) } \\
\text { No= 15 }\end{array}$ & $\begin{array}{c}\text { Group III (severe) } \\
\text { No= 15 }\end{array}$ & $\begin{array}{c}\text { Group IV (control) } \\
\text { No }=\mathbf{1 5}\end{array}$ \\
\hline Mean $\pm \mathrm{SD}$ & $23.5 \pm 7.5$ & $21.3 \pm 6.9$ & $25.6 \pm 8.1$ & $0.8 \pm 0.2$ \\
\hline $\mathrm{t}$ & 11.8452 & 11.5019 & 11.8544 & \\
\hline $\mathrm{P} *$ & $0.0001^{*}$ & $0.0001^{*}$ & $0.0001^{*}$ & \\
\hline
\end{tabular}

$* \mathrm{P} \leq 0.05=$ significant

Table (7): Student (t) test of carboxyhemoglobin (COHb) level in survived and dead patients of group III.

\begin{tabular}{|l|c|}
\hline \multicolumn{1}{|c|}{$\begin{array}{c}\text { Group III (severe) } \\
\text { No }=\mathbf{~ 1 5}\end{array}$} & COHb (\%) \\
\hline Survived patients $(\mathrm{No}=11)$ & $23.3 \pm 7.2$ \\
\hline Died patients $(\mathrm{No}=4)$ & $26.4 \pm 8.7$ \\
\hline $\mathrm{t}$ & 0.7011 \\
\hline $\mathrm{P} * \quad 0.4956$ \\
\hline \multicolumn{2}{|c|}{$* \mathrm{P} \leq 0.05=$ significant. } \\
\hline
\end{tabular}


Table (8): Student (t) test of blood sugar (B.S.) level in group I, II and III compared to control group IV.

\begin{tabular}{|l|c|c|c|c|}
\hline B.S. (mg/dl) & $\begin{array}{c}\text { Group I (mild) } \\
\text { No= 10 }\end{array}$ & $\begin{array}{c}\text { Group II (moderate) } \\
\text { No= 15 }\end{array}$ & $\begin{array}{c}\text { Group III (severe) } \\
\text { No= 15 }\end{array}$ & $\begin{array}{c}\text { Group IV (control) } \\
\text { No= 15 }\end{array}$ \\
\hline Mean \pm SD & $110.2 \pm 19.9$ & $119 \pm 24$ & $154.1 \pm 48$ & $99 \pm 10.2$ \\
\hline $\mathrm{T}$ & 1.8569 & 2.9704 & 4.3488 & \\
\hline $\mathrm{P} *$ & 0.0762 & $0.0060 *$ & $0.0002^{*}$ & \\
\hline
\end{tabular}

$* \mathrm{P} \leq 0.05$ = significant.

Table (9): Student (t) test of blood sugar in survived and dead patients of group III.

\begin{tabular}{|l|c|}
\hline \multicolumn{1}{|c|}{$\begin{array}{c}\text { Group III (severe) } \\
\text { No }=\mathbf{1 5}\end{array}$} & B.S. $(\mathbf{m g} / \mathbf{d l})$ \\
\hline Survived patients $(\mathrm{No}=11)$ & $132.2 \pm 34.2$ \\
\hline Died patients $(\mathrm{No}=4)$ & $180.5 \pm 29.7$ \\
\hline $\mathrm{t}$ & 2.4905 \\
\hline $\mathrm{P} *$ & $0.0271 *$ \\
\hline
\end{tabular}

$* \mathrm{P} \leq 0.05$ = significant.

Table (10): Student (t) test of plasma lactate level in group I, II and III compared to control group IV.

\begin{tabular}{|l|c|c|c|c|}
\hline Lactate umol/ml & $\begin{array}{c}\text { Group I(mild) } \\
\mathbf{N o}=\mathbf{1 0}\end{array}$ & $\begin{array}{c}\text { Group II (moderate) } \\
\mathbf{N o}=\mathbf{1 5}\end{array}$ & $\begin{array}{c}\text { Group III (severe) } \\
\mathbf{N o}=\mathbf{1 5}\end{array}$ & $\begin{array}{c}\text { Group IV (control) } \\
\mathbf{N o}=\mathbf{1 5}\end{array}$ \\
\hline Mean $\pm \mathrm{SD}$ & $2.8 \pm 0.7$ & $4.1 \pm 1.1$ & $8.8 \pm 2.8$ & $1.4 \pm 0.3$ \\
\hline $\mathrm{t}$ & 6.9068 & 9.1714 & 10.1775 & \\
\hline $\mathrm{P} *$ & $0.0001^{*}$ & $0.0001^{*}$ & $0.0001^{*}$ & \\
\hline & $\mathrm{P} \leq 0.05=$ significant.
\end{tabular}

Table (11): Student (t) test of plasma lactate level in survived and dead patients in group III.

\begin{tabular}{|l|c|}
\hline \multicolumn{1}{|c|}{$\begin{array}{c}\text { Group III (severe) } \\
\text { No }=\mathbf{1 5}\end{array}$} & Lactate \\
\hline Survived patients $(\mathrm{No}=11)$ & $7 \pm 1.3$ \\
\hline Died patients $(\mathrm{No}=4)$ & $10 \pm 1.9$ \\
\hline $\mathrm{t}$ & 3.5180 \\
\hline $\mathrm{P} *$ & $0.0038^{*}$ \\
\hline$* \mathrm{P} \leq 0.05=$ significant.
\end{tabular}

Table (12) Correlation Co-efficient between plasma lactates and other variable (CO, B.S. \&PH).

\begin{tabular}{|l|c|c|c|c|}
\hline \multicolumn{1}{|c|}{ Grading } & Group I(mild) & Group II (moderate) & Group III(severe) & R \\
\hline Lactate & $2.8 \pm 0.7$ & $4.1 \pm 1.1$ & $8.8 \pm 2.8$ & $0.735^{*}$ \\
\hline CO & $23.5 \pm 7.5$ & $21.3 \pm 6.9$ & $25.6 \pm 8.1$ & $0.999 *$ \\
\hline B.S. & $110.2 \pm 19.9$ & $119 \pm 24$ & $154.1 \pm 48$ & $-0.928 *$ \\
\hline pH & $7.37 \pm 0.038$ & $7.32 \pm 0.05$ & $7.28 \pm 0.042$ & \\
\hline
\end{tabular}

Correlation will always be between -1.0 and +1.0 . If the correlation is positive, there will be a positive relationship. If it is negative, the relationship is negative. A correlation greater than 0.8 is generally described as strong.

Table (13) Correlation Co-efficient between delay time and plasma lactate.

\begin{tabular}{|l|c|c|c|c|}
\hline \multicolumn{1}{|c|}{ Grading } & Group I (mild) & Group II (moderate) & Group III (severe) & R \\
\hline Lactate & $2.8 \pm 0.7$ & $4.1 \pm 1.1$ & $8.8 \pm 2.8$ & \multirow{2}{*}{$0.996 *$} \\
\hline Delay time & $2 \pm 1$ hours & $3.4 \pm 1.3$ hours & $6.8 \pm 3.3$ hours & \\
\hline
\end{tabular}

Correlation will always be between -1.0 and +1.0 . If the correlation is positive, there will be a positive relationship. If it is negative, the relationship is negative. A correlation greater than 0.8 is generally described as strong.

Table (14) Period of stay in the selected 40 patients with acute carbon monoxide poisoning.

\begin{tabular}{|c|c|c|c|}
\hline Grading & Group I (mild) & Group II (moderate) & Group III (severe) \\
\hline Period of stay & $6.6 \pm 6.3$ hours & $31.0 \pm 12.35$ hours & $3.9 \pm 1.9$ day \\
\hline
\end{tabular}

Table (15): Outcome in the three groups of selected 40 patients with acute carbon monoxide poisoning.

\begin{tabular}{|c|c|c|c|c|c|c|}
\hline \multirow[t]{2}{*}{ Outcome } & \multicolumn{2}{|c|}{$\begin{array}{c}\text { Group I(mild) } \\
(\text { No }=10)\end{array}$} & \multicolumn{2}{|c|}{$\begin{array}{c}\text { Group II (moderate) } \\
\left(\mathrm{No}_{0}=15\right)\end{array}$} & \multicolumn{2}{|c|}{$\begin{array}{c}\text { Group III (severe }) \\
(\text { No }=15)\end{array}$} \\
\hline & No & $\%$ & No & $\%$ & No & $\%$ \\
\hline Survived & 10 & $100 \%$ & 15 & $100 \%$ & 11 & $73.3 \%$ \\
\hline Died & 0 & 0 & 0 & 0 & 4 & $26.6 \%$ \\
\hline
\end{tabular}




\section{Discussion}

Patients with acute carbon monoxide $(\mathrm{CO})$ poisoning have been found to have a correlation between initial clinical severity on admission and blood lactate levels. Recently, it is suggested that the lactate level may be a useful prognostic factor in acute Co poisoning (Moon et al., 2011).

The current study revealed that the highest incidence of carbon monoxide poisoning was found in age group of 21-40 years old, with male incidence more than female and majority of patients came from rural areas (Table 2), This may be attributed to the fact that these groups are commonly exposed to $\mathrm{CO}$ from stoves, traditional heating ways (as burning wood), and other appliances especially if associated with bad ventilation.

As regards the clinical manifestations, the present study revealed that nausea and vomiting were the most common clinical manifestations and occurred in all patients followed by CNS manifestations in order of frequency as shown in (Table 3 ).

By analysis of our treatment, we found that the mild cases respond to $\mathrm{O} 2$ therapy by mouth mask and all moderate and severe patients undergo endotracheal intubation and mechanical ventilation with $100 \% \mathrm{O} 2$ for $6 \mathrm{~h}$ and after stabilizing the patient as regarded hemodynamic status we send them for repeated cession of hyperbaric oxygen therapy in Naser institute hospital as required.

The present study revealed that there was significant decrease in blood $\mathrm{pH}$ in group II \& III in comparison to the control group, while no significant difference was found in group I when compared with the control group (Table 4). Also there was no significant difference between dead and survived severe patients (group III) as regard blood $\mathrm{pH}$ (Table 5). So metabolic acidosis can predict the severity of cases but cannot predict the mortality. The correlation study revealed strong negative correlation between blood pH and plasma lactate levels (table 12) which explained by that the presence of metabolic acidosis in carbon monoxide poisoning is due to the combination of hypoxia, inhibition of cellular respiration, hypotension and increase metabolic demand which increase lactic acid production as end product of all these process (Louise and Kristine, 2004).

These results were in agreement with Lam et al., (2006) who carried a study on 148 cases of acute carbon monoxide poisoning and found that acidosis had prognostic values in evaluation of severity. Neil et al., (2008) demonstrated that arterial $\mathrm{pH}$ was statistically significant predictor of death in patients with acute carbon monoxide poisoning.

In the current study carboxyhemoglobin level was very highly significantly increased in all test groups (I, II, III) in comparison to control group, with mean values nearly the same in the three groups (Table 6 ) and there was no significant difference between $\mathrm{COHb}$ levels of survived and dead patients of group III (Table 7). Also there was weak positive correlation between $\mathrm{COHb}$ levels and plasma lactate level (Table 12). So an elevated carboxyhemoglobin level is a diagnostic of poisoning, but does not predict the mortality or severity of clinical signs and symptoms and this is because the $\mathrm{COHb}$ measurement reflects only the blood levels (which rapidly decline by removal of the patient from exposure place) and does not indicate the degree of tissue involvement (unmeasured tissue uptake of carbon monoxide) (Claude, 2002).

These results are in agreement with Turner et al., (1999) who found that measurement of $\mathrm{COHb}$ concentration is indicated to confirm the diagnosis, but the percentage of $\mathrm{COHb}$ in the blood is not always a good indicator of severity.

Moreover, Hatlestad (2005), reported that although elevated $\mathrm{COHb}$ level is the primary diagnostic indicator of $\mathrm{CO}$ poisoning, it does not predict the severity of clinical signs and symptoms, particularly those affecting the brain. This poor correlation between $\mathrm{COHb}$ levels and neurologic presentation is related to unmeasured tissue uptake of $\mathrm{CO}$ that increases during hypoxia because of competition between carbon monoxide and oxygen at the oxygen-binding sites on hemoproteins).

Also Cevik et al., (2006) performed a study to evaluate the relationship between the Poisoning Severity Score (PSS) and carboxyhaemoglobin $(\mathrm{COHb})$ levels in patients with acute carbon monoxide poisoning. They found that the Mean $\mathrm{COHb}$ level of the severe group was significantly higher than mild and moderate groups but the $\mathrm{COHb}$ levels according to outcome were not significantly different within the patients in the severe group.

Also Lam et al., (2006) performed a study on 148 patients suffering from CO poisoning. They found 25 patients $(16.9 \%)$ were unconsciousness (GCS $\leq 8)$ on arrival. The mean initial carboxyhaemoglobin $(\mathrm{COHb})$ level was $21.0 \%$, and there was no relationship between initial $\mathrm{COHb}$ level with consciousnesses level on arrival.

The present study revealed highly significant increase in blood sugar in group III and group II in comparison with the control group IV, while group I did not show any significant difference when compared with the control group as regard the blood sugar (Table 8). In addition, there was significant increase in the blood sugar in the dead patients when compared with the survived severely intoxicated patients (Table 9) and strong positive correlation between B.S. levels and plasma lactate levels (Table12). Therefore, the blood sugar can predict severe cases, and mortality of $\mathrm{CO}$ poisoning. This may be attributed to the increased glucose induced by stress presumably increases cerebral glycolytic flux, and elevates intracellular and interstitial lactate level, which in turn induces acidosis and edema, resulting in brain damage (Penney et al., 2008).

These results were in agreement with Cevik et al., (2006) who did a study aimed to evaluate the efficacy of the Poisoning Severity Score (PSS) in patients with carbon monoxide poisoning using outcome as the measure and found that high glucose 
levels showed significant relation with poisoning severity score and adverse outcome.

Also Pach et al., (2007) performed a study on 3628 patients with different xenobiotic toxicity and found that severe acute carbon monoxide poisoning was associated with a higher risk of hyperglycaemia

Also Suzanne (2007) found that high blood sugar on admission associated with worse neurologic outcome after carbon monoxide poisoning and it was elevated in most patients presenting with $\mathrm{COHb}$ saturation above $25 \%$. She also found that neurologic outcome in diabetics poisoned with $\mathrm{CO}$ is generally worse than in non-diabetics. She concluded that acute severe carbon monoxide poisoning characterized by hyperglycaemia and this elevation has been linked to increased severity of brain dysfunction.

The present results revealed that the blood lactate level showed high significant increase in all test groups (I \& II \& III) when compared to control group (IV) (Table 10) and the patients of group III (severe CO poisoning) showed the highest mean blood lactate levels. Also the obtained results revealed that the four patients who died were from group III (severe CO poisoning group) and they had the highest blood lactate values which showed very highly significant increase when compared with the survived patients of the same group (Table 11). This could be attributed to the fact that carbon monoxide poisoning is associated with tissue hypoxia. This tissue hypoxia is due to the reduction of the oxygen-carrying capacity of the blood and the concomitant shift of the oxyhemoglobin dissociation curve to the left, which lead to lactate accumulation and lactic acidosis (Milan, 2000)

By analysis of the four patients who died, we found that they were presented with shock, metabolic acidosis and after long delay time and one of them had high blood sugar \& DKA. from these data we can consider that the high blood lactate levels in these patients was not only correlated to the $\mathrm{CO}$ by itself but there is other contributory factors which is also a sequale of $\mathrm{CO}$ poisoning e.g. hypotesive state, high blood sugar and acidosis which all increase the plasma lactate. Also the long delay time in these 4 patients and presence of strong positive correlation between the delay time and plasma lactate levels (table 13) indicates that the rapid transfer of the patient to the hospital and even early pre-treatment with oxygen therapy in the ambulance is an important factor in the treatment and improve the outcome (as what happen with mild cases). So plasma lactates can be good sensitive indicator of the severity and the complication of $\mathrm{CO}$ poisoning but not specific for the diagnosis alone and need other contributory test as $\mathrm{CO}$ level or history of exposure. From these 4 dead patients two patients died from post anoxic brain damage and multiorgan failure, one patient died from ARDS and unresponding to advanced ventilation setting and the fourth one died from intractable shock and acute renal failure.

The current results also are in agreement with Kubat and Zboril (1995) who stressed on the significance of the examination of lactic acid level at $\mathrm{CO}$ poisoning in cases where the level of carbonyl haemoglobin could not be determined because of device trouble. They concluded that routine examination of acid base balance and lactate level is very important for the consideration of the severity of carbon monoxide poisoning and lactate determination is probably even more significant for the total prognosis of the patient.

On the other side Lamine et al., (2003) did a study on 146 patients poisoned with $\mathrm{CO}$ and found that plasma lactate is mildly elevated in pure CO-exposed patients. This mild increase and the extensive overlap between the groups of neurological impairment severity do not suggest the usefulness of systematic plasma lactate measurement in pure $\mathrm{CO}$ poisoning.

Moreover, Inoue et al., (2008) also did a study in acute $\mathrm{CO}$ poisoning and found that the initial blood lactate may correlate with the patient outcomes and prove to be a useful prognostic factor.

Also Moon et al., (2011), performed a study on 80 patients that presented to the Chonnam National University Hospital after CO poisoning. They found that the patients with high initial lactate had an altered mental status on admission. The multivariate analysis showed that high lactate level was associated with serious complications and the need for intensive medical treatment on admission. The results of this study showed that the initial lactate was useful for patient prognosis after $\mathrm{CO}$ poisoning.

\section{References}

Bateman D (2003): Carbon Monoxide. Medicine 31 (10): 233. doi: 10, 1383/medc.

Cevik A, Unluoglu I, Yanturali S et al., (2006): Interrelation between the Poisoning Severity Score, carboxyhaemoglobin levels and inhospital clinical course of carbon monoxide poisoning. International Journal of Clinical Practice. Dec; 60(12): 1558.

Claude A (2002): Carbon monoxide poisoning.NEJM; Volume 347 Number 14:1054.

Hatlestad D (2005): Carbon Monoxide Poisoning: Incidence, Diagnosis \& Treatment.Toxicol Appl Pharmacol 105(2):340.

Inoue S, Saito T, Tsuji T et al., (2008): Lactate as a prognostic factor in carbon monoxide poisoning: a case report. Am J Emerg Med. Oct; 26(8):966.e1-3.

Kubát K and Zboril M (1995): Determination of serum lactic acid and the acid-base equilibrium in carbon monoxide poisoning. Vnitr Lek. Aug; 41(8):545-8.

Lam K, Fung H and Kam C (2006): The severity and prognostic markers of 148 cases of carbon monoxide poisoning by burning charcoal. Hong Kong Journal of Emergency Medicine Vol. 13(1) Jan: 6-16.

Lamine M, Bruno M and Stephen W (2003): Is elevated plasma lactate a useful marker in the evaluation of pure carbon monoxide poisoning? Intensive Care Medicine, Volume 29, Number 8, Pages 1372-1375. 
Louise W and Kristine A (2004): Carbon monoxide poisoning.Emerg Med Clin. N. Am. 22:985.

Marbach E and Weil M (1967): Rapid enzymatic measurement of blood lactate and pyruvate. Clin. Chem.1967; 13:314-25.

Milan JH (2000): Effect of Carbon Monoxide on Work and Exercise Capacity in Humans. In: Carbon Monoxide Toxicity, Edited by David G. Penney, Informa Healthcare 2000, Chapter 5Pages 101-134

Moon JM, Shin MH and Chun BJ (2011): The value of initial lactate in patients with carbon monoxide intoxication: in the emergency department. Hum Exp Toxicol. Aug; 30 (8):836-43.

Neil B, Niels M and Hauff BE (2008): Risk factors for short-term mortality from carbon monoxide poisoning treated with hyperbaric oxygen. Crit Care Med Vol. 36, No. 9, 2523-2527

Pach D, Szurkowska M, Szafraniec K et al., (2007): Carbohydrate metabolism in acute poisoning with xenobiotics. B.v Przegl Lek; 64(45):243-7.

Penney D, Helfman C and Hull J (2008): Elevated blood glucose is associated with poor outcome in the carbon-monoxide-poisoned rat. Journal Title Toxicology, vol. 54, n²-3, pp. 287.

Pepe G, Castelli M, Nazerian P et al., (2011): Delayed neuropsychological sequelae after carbon monoxide poisoning: predictive risk factors in the Emergency Department. A retrospective study. Scandinavian Journal of Trauma, Resuscitation and Emergency Medicine, 19:16

Prockop LD and Chichkova RI (2007):"Carbon monoxide intoxication: an updated review". Journal of the Neurological Sciences 262 (12): $122-130$

Suzanne R (2007): Treatment of Carbon Monoxide Poisoning. In Carbon Monoxide Poisoning, David G. editor, Published by CRC Press, Ch 16.4.4 p 352 .

Tomaszewski C (2006): Carbon monoxide poisoning.In: Goldfrank's toxicologic emergencies. 8th edition, Goldfrank LR, Flomenbaum NE, Lewin NA, Howland MA, Hoffman RS, Nelson LS, editors. New York: McGraw-Hill Ch120:1689.

Trinder P (1969): Determination of glucose in blood using glucose oxidase with an alternative oxygen receptor. Ann. Clin. Biochem; 6:24.

Turner M, Esaw M and Clark R (1999): Carbon monoxide poisoning treated with hyperbaric oxygen: metabolic acidosis as a predictor of treatment requirements. J Accid Emerg Med. 1999 Nov; 16(6):461.

Weaver LK (2009): "Clinical practice. Carbon monoxide poisoning". The New England Journal of Medicine 360 (12): 1217-1225.

\section{الملخص العربي \\ البلازما لاكتات كعامل تكهني في حالات التسمم الحاد بغاز أول أكسيد الكربون \\ هاني محمد عبد الرازق 1 و محمود بدر عبد الوهاب2}

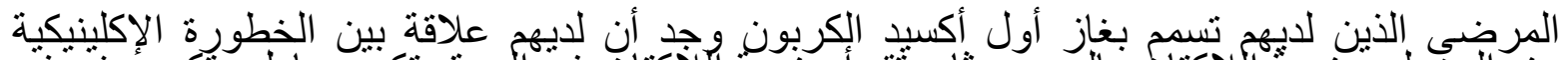

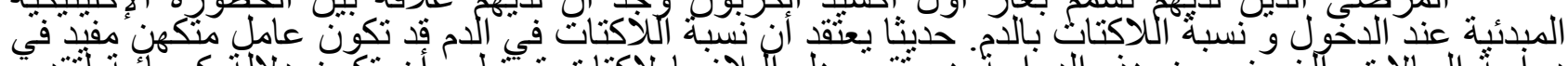

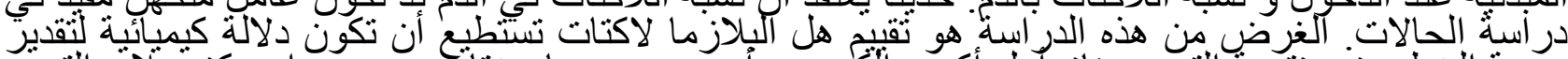

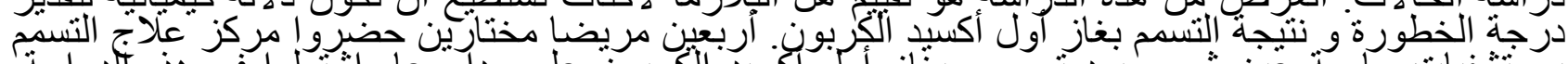

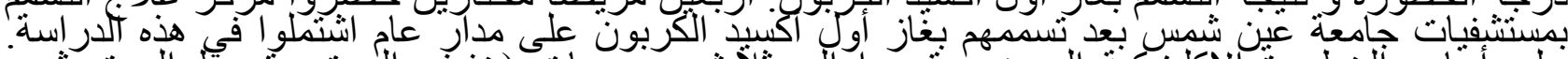

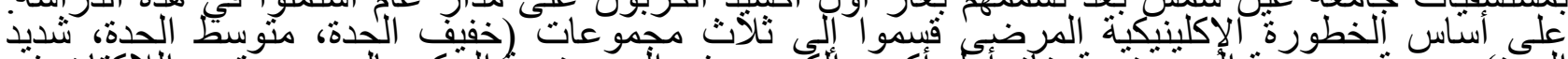

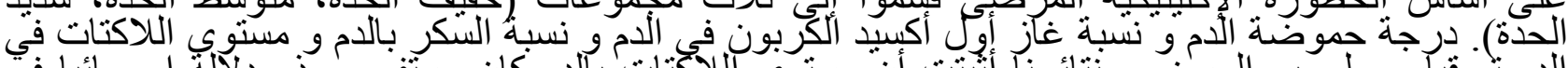

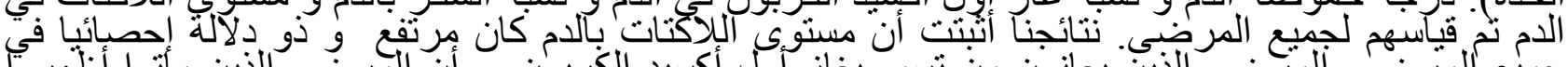

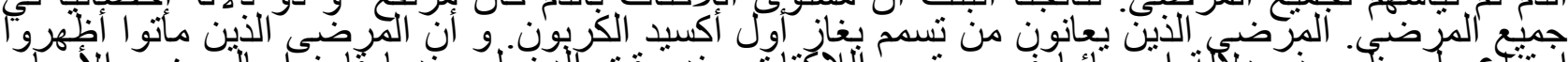

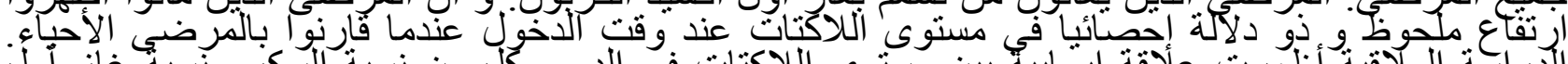

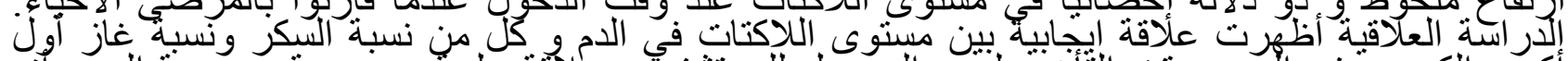

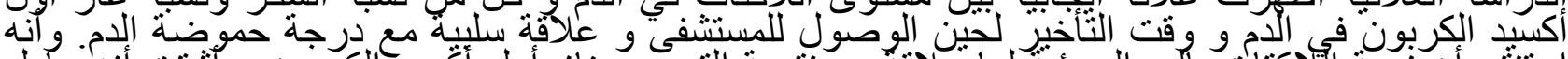

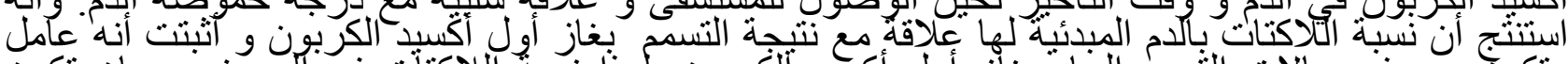

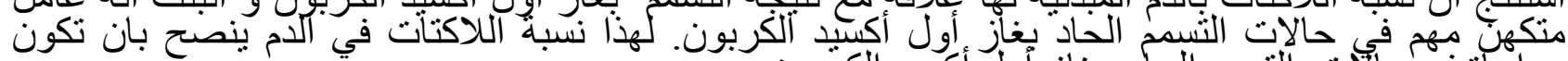

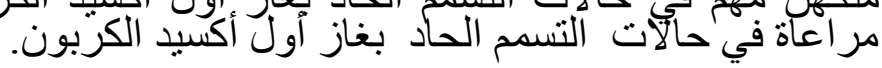

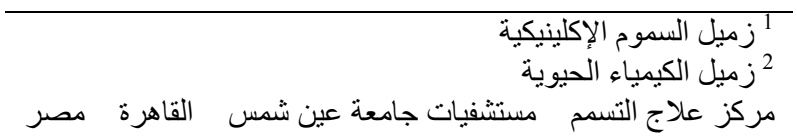

